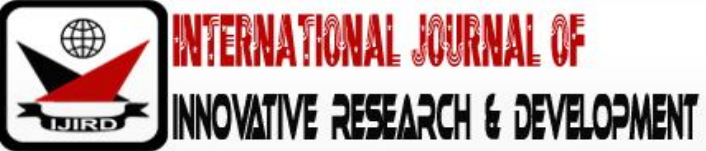

ISSN 2278 - 0211 (Online)

\section{Evaluation of Selected Quality Parameters in Edible Sesame Oil Samples Produced From Jaffna District in the Northern Part of Sri Lanka}

\begin{tabular}{c}
\hline G.Moganatharsa \\
Student, Department of Agricultural Chemistry, University of Jaffna, Sri Lanka \\
Dr. S.Vasantharuba \\
Senior Lecturer, Department of Agricultural Chemistry, University of Jaffna, Sri Lanka \\
Dr. S.Balakumar \\
Senior Lecturer, Department of Bio Chemistry, University of Jaffna, Sri Lanka
\end{tabular}

\begin{abstract}
:
This study was conducted to measure the quality parameters of locally produced edible sesame oil in Jaffna district, Sri Lanka. Ten processing centers (66\% of total number of processing centers) were selected randomly from seven divisional secretariats area in Jaffna district, Sri Lanka. Two freshly extracted oil samples were collected in two different time period from each processing center. Three replicate tire values of each twenty samples were analyzed and the average values were taken into consideration. All parameters of the samples were determined according to Sri Lanka Standard (SLS) 313 procedure and the results were compared with Sri Lanka Standard 231:2013. The results of this study showed that free fatty acids value and color of all samples complied with the SLS standard. Oil samples from seven processing centers only contained the acceptable level of saponification value. Refractive index and peroxide value of all samples except one, met the standards. Samples obtained from five processing centers (50\%) contained the acceptable values for all five quality parameters. Thus, it can be concluded that most of the sesame oils produced in Jaffna district need some modification or improvements in processing methods to meet the quality standards specified in SLS.
\end{abstract}

Keywords: Color, free fatty acid value, peroxide value, refractive index, saponification value

\section{Introduction}

Sesame oil is extracted from the roasted Sesamum indicumL seed by pressing and consumed without any processing as natural flavored oil in the Asian countries (Islam et al., 2016).The presence of poly unsaturated fatty acids increases the demand of sesame oil. Due to the edible purpose the standard of oil should be analysed to ensure its quality. The quality of sesame oil is influenced by many physiochemical parameters such as Color, Free fatty acid value, Peroxide value, Refractive index, and Saponification value. According to the SLS 231:2013, the saponification value ranges 188-193, refractive index at $40^{\circ} \mathrm{C}$ ranges $1.465-1.469$, color less than 20 , free fatty acid (as oleic) value less than 3 and peroxide value less than 10 can be an indication for good quality sesame oil. Free fatty acid value is the amount of $\mathrm{KOH}(\mathrm{mg})$ required to neutralize free fatty acid contained in $1 \mathrm{~g}$ of oil. It determines the purity of oils. The higher value oils can't be used for cooking purpose (Hasan et al., 2016). Color of the cooking oil is due to the presence of carotenoids and pigments (Michael et al., 2005). Polymers and aldehydes are responsible for red and yellow color respectively. Lipase enzyme activity also influence in the color of oil. More color value may be due to the poor bleaching and exposure to high temperature for long time period (Tahir et al., 2012). The saponification value is milligrams of potassium hydroxide required to saponify $1 \mathrm{~g}$ of fat (Odoom et al., 2015).Saponification value shows the inversely relationship with the average molecular weight of the fatty acids in the oil fractions (Hasan et al., 2016).Saponification value is used to detect the adulteration(Odoom et al., 2015). Refraction is the change of direction of light rays as it travels the change of direction of light rays as it travels through one substance to another. Refractive index of oil used to detect rancidity in edible oil and also indicates the purity. Peroxide value is used to measure the oxidative rancidity. It is expressed in milli-equivalent of oxygen per kg of oil (Anagye et al., 2015).Locally extracted edible sesame oil plays a major role of the edible oil industry in the northern part of Sri Lanka. However, the quality of the locally produced oils is not known since no laboratory tests are conducted to determine the quality of its. Therefore, proper quality tests should be done in order to improvethis for edible purpose. This study was aimed to determine the quality of edible sesame oil produced by processing centers in the Jaffna district, Sri Lanka. 


\section{Methodology}

\subsection{Sample Collection for Sesame Oil}

The different samples of Sesame oilwere collected from randomly selected ten processing centers in Jaffna District, Sri Lanka during two different production times (February - March 2017) under required conditions. The oil samples were kept at room temperature and brought to the laboratory for analysis.

\subsection{Determination of Saponification Value, Free Fatty Acid Value, Refractive Index, Color and Peroxide Value}

Saponification value, free fatty acid value and refractive index were determined by SLS 313 procedures. Peroxide value was determined by AOAC 17th edition 2000 procedure. Pike 2003 method was used to determine the color.

\subsubsection{Determination of Refractive Index}

Initially the refract meter (ATAGO) was calibrated. Then the oil filled into designated space of the instrument and reading was taken. The room temperature was also measured simultaneously.

It was calculated by using the following formula:

The refractive index at $40^{\circ} \mathrm{C}$ may be calculated from the result obtained at any other temperature by subtracting 0.00036 therefrom for each degree centigrade by which the temperature of the experiment is lower than $40^{\circ} \mathrm{C}$ or by adding 0.00036 for each degree centigrade by which the temperature of the experiments higher than $40^{\circ} \mathrm{C}$.

\subsubsection{Determination of free fatty acids}

$40 \mathrm{~g}$ of oil was weighed. $50 \mathrm{ml}$ of the ethanol and about $0.5 \mathrm{ml}$ phenolphthalein indicator was added and it was brought to the boil on a water bath, while hot. It was titrated with the aqueous alkali solution.

It was calculated by using the following formula:

Free fatty acids, as lauric acid, present by mass $=\frac{\mathrm{V} * 20.0 \mathrm{~N}}{\mathrm{M}}$ Where,

$\mathrm{V}=$ Volume, in milliliters of $\mathrm{N}$ alkali required

$\mathrm{M}=$ Mass, in grams of oil taken

$\mathrm{N}=$ Normality of the alkali solution used

\subsubsection{Determination of Saponification value}

Two grams of the oil was weighed $.25 \mathrm{ml}$ of the ethanolic solution of potassium hydroxide and it was boiled continuously for one hour under reflux condenser. The excess of alkali was titrated with the hydrochloric acid. A blank determination was made at the same time under the same conditions.

It was calculated by using the following formula:

Saponification value $=\frac{(\mathrm{V} 1-\mathrm{V} 2) \mathrm{N} * 56.1}{\mathrm{M}}$

$\mathrm{M}=$ Mass in grams of the oil taken

$\mathrm{V}_{1}=$ Volume in milliliters, of hydrochloric acid required for the blank

$\mathrm{V}_{2}=$ Volume in milliliters, of hydrochloric acid required for the oil

$\mathrm{N}=$ Normality of $\mathrm{HCl}$ used

\subsubsection{Determination of peroxide value}

3-5 $\mathrm{g}$ of sample as weighed. $30 \mathrm{ml}$ of the acetic acid: chloroform solution ( $2: 1 \mathrm{v} / \mathrm{v})$ was added. The flask was swirled until the lipid sample was completely dissolved. Then saturated potassium iodide solution was added. Then $30 \mathrm{ml}$ of deionized water was added and stoppered. Then it was shaked. If the starting color of the solution was deep orange, it was titrated slowly against $0.1 \mathrm{~N}$ sodium thiosulphate solution until the color lighten.an initial light amber color was indicative of low concentration of peroxide thus, $1 \mathrm{ml}$ of starch was added before titrating with sodium thiosulfate. It was titrated until the blue color was disappeared in the aqueous. Similarly, a blank sample was prepared devoid of oil sample.

It was calculated by using the following formula:

Peroxide value $=\frac{(\mathrm{S}-\mathrm{B}) * \mathrm{~N} * 1000}{\mathrm{~W}}$

Where peroxide value $=\mathrm{mEq}$ peroxide per $\mathrm{Kg}$ of sample

$\mathrm{S}=$ Volume of titrant $(\mathrm{ml})$ for sample

$\mathrm{B}=$ Volume of titrant $(\mathrm{ml})$ for blank

$\mathrm{N}=$ normality of $\mathrm{v}(\mathrm{mEq} / \mathrm{ml})$

$1000=$ conversion of units $(\mathrm{g} / \mathrm{Kg})$

$\mathrm{W}=$ Sample mass $(\mathrm{g})$

\subsubsection{Determination of color}

The oil sample was poured in a quartz cuvette and placed in a spectrophotometer (Thermo scientific). Absorbance of the oil sample was read at the following wavelengths; 460, 550, 620, and $670 \mathrm{~nm}$.

It was calculated by using the following formula:

Photometric color index $=1.29\left(\mathrm{~A}_{460}\right)+69.7\left(\mathrm{~A}_{550}\right)+41.2\left(\mathrm{~A}_{620}\right)-56.4\left(\mathrm{~A}_{670}\right)$ 


\subsection{Statistical Analysis}

All experiments were carried out in replicates. Statistical analyses were done by SPSS 20 and MS Excel 2013.The mean, standard deviation, and standard error were obtained by SPSS 20 and MS Excel 2013.The means of results were compared with the Sri Lanka Standard specification value.

\section{Results and Discussion}

The quality of edible sesame oil was analyzed by physicochemical parameters such as color, free fatty acid value, peroxide value, refractive index, and saponification values. Table 1 depicted the results of this study:

\subsection{Free Fatty Acid (As Oleic Acid) Percent by Mass of Sesame Oil}

Free fat acid value indicates the amount of free fatty acid presents in the oil. The value increases reduce the cooking purpose possibility (Anagye et al., 2015). According to the SLS specification value 231:2013, the free fatty acid (as oleic acid) percent by mass is less than three. The results (table 1) showed that the mean free fatty acid values of sesame oil from ten processing centers met the specification value. It ranges from 0.9 to 2.4 .

\subsection{Saponification Value of Sesame Oil}

According to the SLS specification value 231:2013, the saponification value ranges between $188-193 \mathrm{mg} \mathrm{KOH} / \mathrm{g}$ oil. The result (table 1) showed that the mean saponification values of oil from seven processing centers met the SLS specification value; however, three processing centers did not meet the specification value. In that, the value was above the specification value for two processing centers and below the specification value for one is processing centers. Among the collected sample 198 was the highest mean saponification value and 184 was the lowest mean saponification value. The higher saponification value may be due to the shorter average chain length of the fatty acids and lower average molecular weight of the fatty acids and vice versa relationship reasons for lower mean saponification value (Hasan et al., 2016).

\subsection{Refractive Index at $40^{\circ} \mathrm{C}$ of Sesame Oil}

The refractive index is the indication of the purity of oils (Mohammed et al., 2008). According to the SLS specification value 231:2013, the refractive index ranges between 1.465-1.469. The result (table 1) showed that the mean refractive index value of nine processing centers were within the specification value. One of the processing centers didn't meet the SLS specification value. It is higher than upper specification vale for RI. It may be due to the rancidity (Mohammed et al., 2008).

\subsection{Peroxide Value of Sesame Oil}

According to the SLS specification value, the peroxide value for edible oil is less than 10 . The results (table 1) showed that the samples of the nine-processing center were within the stipulated limits. Sample of one processing center didn't meet the standard. It may be due to the rancidity and also higher peroxide value resulted in that sample may be due to the poor packaging and storage conditions (Tahir et al., 20112).

\subsection{Color of Sesame Oil}

According to the SLS specification value 231:2013, color of sesame oil is less than 20. The results (table 1) showed that all the collected sesame oil samples were within the stipulated limits recommended by SLS.

\begin{tabular}{|c|c|c|c|c|c|}
\hline Sample Number & Color & $\begin{array}{c}\text { Free Fatty Acid } \\
\text { Value } \\
\text { (Mg KOH/ G) }\end{array}$ & $\begin{array}{c}\text { Peroxide Value } \\
\left.\text { (Meq } \mathrm{O}_{2} / \mathrm{Kg}\right)\end{array}$ & Refractive Index & $\begin{array}{c}\text { Saponification } \\
\text { Value } \\
\text { (Mg KOH/ G) }\end{array}$ \\
\hline 1 & $2.253 \pm 0.02$ & $1.4 \pm<0.01$ & $8.7 \pm<0.01$ & 1.469 & $190 \pm 0.01$ \\
\hline 2 & $2.255 \pm 0.09$ & $2.4 \pm \varangle 0.01$ & $8.7 \pm \varangle 0.01$ & 1.468 & $197 \pm 1.67$ \\
\hline 3 & $3.432 \pm 0.10$ & $2.2 \pm 0.03$ & $8.7 \pm<0.01$ & 1.469 & $193 \pm 0.08$ \\
\hline 4 & $4.974 \pm 0.19$ & $1.9 \pm 0.01$ & $8.7 \pm 0.01$ & 1.470 & $193 \pm 0.48$ \\
\hline 5 & $3.981 \pm<0.01$ & $1.6 \pm 0.01$ & $8.7 \pm<0.01$ & 1.468 & $184 \pm 0.63$ \\
\hline 6 & $2.252 \pm 0.22$ & $1.9 \pm \varangle 0.01$ & $11.2 \pm 0.01$ & 1.469 & $189 \pm 0.05$ \\
\hline 7 & $7.83 \pm 0.14$ & $0.9 \pm 0.01$ & $8.7 \pm<0.01$ & 1.465 & $190 \pm 0.41$ \\
\hline 8 & $9.175 \pm 0.07$ & $1.2 \pm<0.01$ & $8.7 \pm<0.01$ & 1.467 & $198 \pm 0.75$ \\
\hline 9 & $1.057 \pm 0.29$ & $2.2 \pm 0.02$ & $10.0 \pm 0.01$ & 1.468 & $188 \pm 1.28$ \\
\hline 10 & $1.677 \pm<0.01$ & $2.3 \pm 0.01$ & $8.8 \pm<0$ & 1.468 & $192 \pm 0.47$ \\
\hline
\end{tabular}

Table 1: Physico Chemical Properties of Some Edible Oils Available in Jaffna District

Values are the mean \pm standard deviation of replicates

\section{Conclusion}

According to the results of the present study, free fatty acid values of sesame oil from ten processing centers met the specification value. For the saponification value, mean saponification value of seven processing centers met the SLS specification value; however, three processing centers did not meet the specification value. For mean refractive index value, mean refractive index value of nine processing centers within the Specification value while one of the processing centers didn't. For peroxide value, mean value of the nine-processing center were within the stipulated limits however one 
processing center didn't meet the standard. Color of all the collected sesame oil samples were within the stipulated limits recommended by SLS. When all parameters are concerned oils from two processing centers were found to be suitable for edible purpose. Therefore, based on the results of this study it can be decided they can be used for edible purpose with some improved process.

\section{References}

i. Islam., F. Rafaqat., A. G. Basharat ., A. Muhammad „,A. F. Ling., X. Ullah .,N. and Weijun . 2016. Sesame. Breeding Oilseed Crops for Sustainable Production, 135-147.http:/ / dx.doi.org/ 10.1016/ b978-0-12-801309-0.00006-9.

ii. Hasan, S., Rownok Jahan, Md., Ashraful Alam., Khodeza Khatun., Mst. and Al-Reza, S.M, 2016. Study on physicochemical properties of edible oils available in Bangladeshi local market, Archives of Current Research International, 6(1):1-6. http:/ / dx.doi.org/ 10.9734/ acri/ 2016/ 29464.

iii. Michael., N. Yunsheng .and L.Sylvester .,O.2005. Quality changes in chicken nuggets fried in oils with different degrees of hydrogenatation,thesis McGill University., Macdonald Campus, Canada

iv. 4)Tahir.,M. Ahmad, A. and Khalid, N. 2012. Quality evaluation and safety assessment of different cooking oils available in Pakistan. Journal of the Chemical Society of Pakistan, 34(3).518:525.

v. 5)Odoom, W. and Eduse, V.O. 2015. Evaluation of Saponification value, Iodine value and Insoluble impurities in Coconut Oils from Jomoro District in the Western Region of Ghana. Asian Journal of Agriculture and Food Sciences, 3(5):494-499.

vi. Anagaye,S.S . And Maduelosi, N.J,2015.Comparative study of the physicochemical properties of some refined vegetable oils sold in the Mile One Market and some departmental stores in Port Harcourt, Rivers State.Nigeria Journal of the Food science and Quality Management,3(9):16-19.

vii. Mohammed,M..and Hamza,Z.U,2008.Physicochemical Properties of Oil Extracts from Sesamum Indicum L.Seeds Grown in Jigwa State-Nigeria. Journal of Applied Science and Enviromental Management,12(2):99-101. http:/ / dx.doi.org/ 10.4314/ jasem.v12i2.55542.

viii. $\quad$ Sri Lanka Standard 231:2013 Specification for Sesame Seed Oil .2013.3-7. 